\title{
THE LINK BETWEEN STUDENTS' SATISFACTION WITH FACULTY, OVERALL STUDENTS' SATISFACTION WITH STUDENT LIFE AND STUDENT PERFORMANCES
}

\section{Zoran Mihanović, Ana Barbara Batinić, Jurica Pavičić}

(1) University of Split, Faculty of Economics

(2) University of Split, Faculty of Economics (3) University of Zagreb, Faculty of Economics and Business

Zoran Mihanović, PhD University of Split, Faculty of Economics Cvite Fiskovića 5, Split, Croatia E-mail: zmihanov@efst.hr

Article info Paper category: Preliminary paper Received: 11.2.2016. Accepted: 15.3.2016. JEL classification: A29, J2 


\begin{abstract}
Customer satisfaction has long been recognized as a central concept of all business activities. Satisfaction can serve as an indicator of success of the company, both in the past and present, as well as an indicator of future performance. High quality service to students is a prerequisite of maintaining competitiveness in the market of higher education. A relationship that is created between the expectations of students and their satisfaction with the quality of service that provides educational institution plays an important role in shaping the reputation of academic institutions. Academic institutions are becoming aware of the importance of student satisfaction, because satisfaction positively influences their decision to continue their education at this institution, and the positive word of mouth that will attract prospective students. Satisfaction will affect student motivation, and therefore their performance. This paper provides insight into the marketing aspects of customer satisfaction, primarily insight into the satisfaction of students in the educational sector. The aim is to establish the influence of satisfaction various factors related to the university and higher education to the satisfaction of student life, and does student life satisfaction affect the overall happiness and student performance. The research was conducted on the student population of the University of Split, on a sample of 191 respondents. The research was conducted with the help of online survey questionnaire. The claim that student's satisfactions with housing affect the satisfaction with the quality of student life is rejected. The results confirmed that the student's satisfaction with university contents, university bodies and services, teaching, teaching methods and academic reputation affects the satisfaction of student life and student life satisfaction affect the student performance.
\end{abstract}

\title{
Keywords:
}

higher education; satisfaction with the student life; student performance; Croatia 


\section{INTRODUCTION}

Many authors have elaborated the subject of students' satisfaction and overall life satisfaction in order to determine if there was a connection between the students' personal satisfaction and the achieved success during studying and to establish what causes student satisfaction. An established system for quality assurance is the fundamental requirement for the creation of an integrated European higher education area, recognition of diplomas, and mobility of people within the European labour area (Budak, Slijepčevič, Švaljek, 2009). The basis for establishing and implementing quality assurance in the Republic of Croatia is the Bologna Declaration, while the Standards and Guidelines for Quality Assurance in the European Higher Education Area represent the fundamental document in this context. The five key elements that should be contained in all the national quality assurance systems have been set out by the Berlin Communiqué, and these refer to: internal evaluation, external evaluation, involvement of students, publication of results, and international participation (Lučin, 2007). The development of the higher education quality assurance has considerably moved forward, and several major turning points have been made in terms of cooperation between the European countries (Eurostat, 2012). In the period from 2001 to 2014 , the share of the highly educated in the age group of 25 to 35 years was examined. The figures on the highly educated collected from the 28 European Union countries were compared to those obtained in the Republic of Croatia. The European Union countries recorded a constant growth in the number of the highly educated, while the Republic of Croatia recorded an increase before 2010, followed by stagnation until 2012, and re-increase in the period from 2012 to 2014 (Eurostat, 2012.). Students across the European higher education system study in different economic conditions, which need to be borne in mind during all the European discussions on the issue of student mobility and graduation (Šćukanec, 2010).

Figure 1.: Comparison of highly educated people in the age group of 25 to 35 years in the European Union and the Republic of Croatia

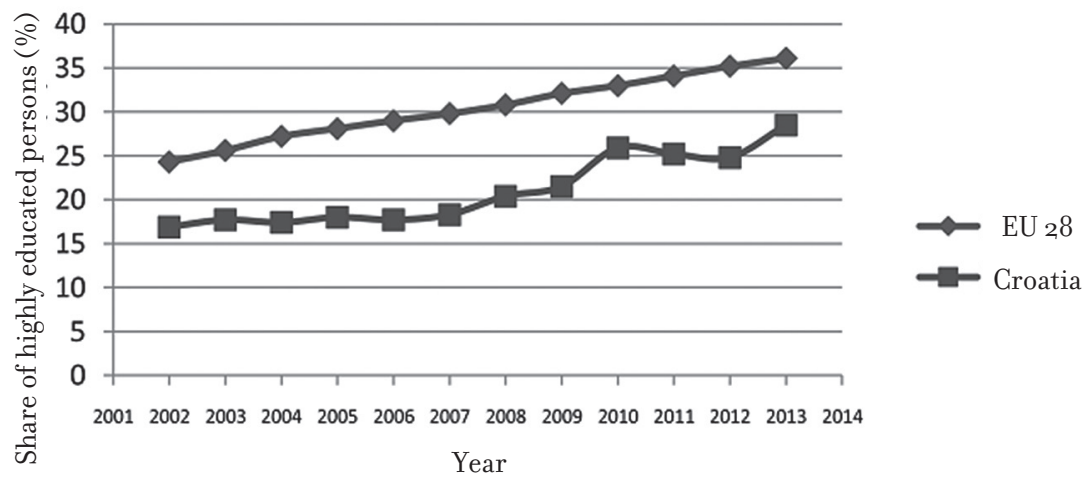

Source: http://epp.eurostat.ec.europa.eu/portal/page/portal/statistics/theme 
From all of the above stated, the importance of students' satisfaction with the quality of student life can also be surmised, which represents a broad term that covers a number of variables pursuant to which the conclusions are made on whether the students are pleased with the quality of life at a particular faculty. Numerous authors have looked into the subject of students' satisfaction, which directly binds the notion of the quality of teaching and professors themselves, the quality of accommodation units, public transport, nightlife, sports and recreational facilities nearby the faculty, employment opportunities during the studies, the quality of food in canteens, and the quality of work of other faculty bodies (library, registry, and others). These results can be of great importance for the faculties observed since they will point out to the advantages that should be preserved, but also to the disadvantages that should be eliminated in order to maintain a good image compared to other faculties and hence directly influence the attraction of new students.

The main goal of this study is determination the extent to which certain factors of life, both general and student life, affect the overall satisfaction with the studying experience and how this is connected with students performances. Thus, it will be explored relationship between: students' satisfaction with their faculty and students' satisfaction with student life; students' satisfaction with the teaching methods and academic reputation and students' satisfaction with student life; students' satisfaction with the faculty facilities, faculty bodies, and faculty services and the overall satisfaction with student life; students' satisfaction with their housing and the overall satisfaction with student life; students' satisfaction with student life and student performance.

\section{MARKETING ASPECTS OF CONSUMER SATISFACTION}

\subsection{Consumer satisfaction in the profit sector}

Satisfaction can be defined as a judgment on the performances of a product or service on the basis of the cognitive (functional) and psychological (emotional) values of the product (Kesić, 2006). Customer satisfaction can serve as an indicator of the success of a business in the past and present, as well as an indicator of its success in the future. Consumer satisfaction is a predictor of repeated purchase and is expressed by consumer loyalty (Vranešević, 2000). Consumer satisfaction lies at the core of the marketing concept and has the leading position in the marketing theories (Dubrovski, 2001). It is based on the postulation that profit will be realized by meeting consumer demands. On the other side, one should also take into account the permanent presence of the danger of spreading unfavourable information on a product, existing among the dissatisfied consumers. Numerous individuals have examined this danger (Collier, 1994, Desatnick, 1989, Hopson \& Scally, 1989, Vavra, 1992, retrieved from: Dubrovski, 2001). Young and Ennew (2001) believe the link between 
consumer satisfaction and business performance is quite simple. Satisfied consumers buy more often (loyalty), so the authors argue that it is cheaper to serve loyal consumers and that they are less price-sensitive, due to which business costs are lower, and profits higher. Researching the correlation between employee and consumer satisfaction, Heskett et al. (1997) concluded that an employee's positive experiences, attitudes, satisfaction, commitment, and positive assessment of the organizational climate are related to increased levels of consumer satisfaction. Many theoreticians have persistently been discussing the impact of business performance on consumer satisfaction (Harter et al., 2002). In the banking sector, it was determined that higher consumer satisfaction leads to increased "cross-selling", and that, based on an insight into the user database of certain banks, consumer satisfaction was the leading indicator of revenue and growth (Anderson, Sullivan, 1993). Some authors have been observing the relationship between consumers and businesses throughout the life cycle, and believe that the relationship between a consumer and a business goes through different phases of that life cycle. The business has to be prepared to identify the ongoing phase of that life cycle in order to be able to react to consumer expectations (Dwyer, Schurr \& Oh, 1987, Bruhn, 2003, retrieved from: Gelade, Young, 2005). Various researches show that consumers have had enough of poor services and that increased satisfaction has a positive impact on personal spending, cash flow and business performance (Rogers, Saenz, 2007).

\subsection{Students' satisfaction in the higher education sector}

The non-profit sector represents the individuals and organizations who help their society become a community of responsible individuals oriented towards personal / family progress, but also the progress of the community they belong to (Pavičić, 2003). Many non-profit organizations are becoming aware of the fact that recognizing the needs of their customers is the key factor in the success of their business. As non-profit managers become increasingly sophisticated, and non-profit organizations struggle to survive in the ever-changing environment, the fact that organizations need to act in a way that satisfies their customers becomes extremely important (Siri, 1987). Increased social sensitivity of the community poses a number of challenges before different businesses and organizations, according to which the businesses have to operate successfully and, in doing so, pay attention to the welfare of the community and reduce all the harmful and negative activities to a minimum (Glavočević, Radman Peša, 2013).

General welfare marketing is one of the forms of the socially responsible business through which organizations attempt to meet the challenges posed before them by different interest and influential groups (Glavočević, Radman Peša, 2013). Businesses and non-profit organizations achieve the greatest rewards by applying the concept of the general welfare marketing, however, consumers also get awarded with 
the sense of a perceived additional value that results from their purchase. In addition, consumers gain the ability to distinguish between competing manufacturers, and can meet their altruistic needs by helping the social community (Baron et al., 2000, retrieved from Gupta, Pirsch, 2006). Polonsky and Speed (2001) have found that the general welfare marketing and its impact on consumers may cause certain risks and concern for them. Consumers can be misguided by the excessive generosity provided by businesses through applying the concept of the general welfare marketing. This can lead to the realization that charitable organizations actually no longer need help, which is why they stop making contributions and the amount of raised funds gets reduced. Srbljinović (2012) believes that there is a positive relationship between customer loyalty and corporate social responsibility. Modern business practices make customer satisfaction their top priority and increasingly invest in socially responsible businesses.

A high quality service is a prerequisite for surviving and maintaining market competitiveness in higher education. The relationship between students' expectations and their satisfaction with the quality of the services provided by an educational institution plays an important role in shaping the reputation of academic institutions. Understanding and knowing the expectations of students may constitute a source of information for higher education institutions, and these could be involved in the creation of their strategy of developing their service quality and gaining an advantage on the market of higher education (Sander et al., 2000). Each interest group in higher education (students, teaching staff, government, etc.) has a special outlook on the quality depending on the specific needs of each individual group. The economic literature on service quality is usually based on the comparison of consumer expectations and their satisfaction with the services actually provided (Zeithmal et al., 1990). O'Neill and Palmer (2004) define service quality in higher education as the difference between students' expectations on what they will get from a higher education institution and their satisfaction with the realized expectations.

Douglas et al. (2006) list four main reason why it is necessary to look into the opinions, expectations and satisfaction of students: (1) to get evidence that students have an opportunity to comment on the situation, and to use these information in improving the services of a higher education institution; (2) to encourage students to reflect on the process of their acquisition of knowledge; (3) to allow the institutions to set the quality criteria and to create the indicators that might contribute to the reputation of their institution on the market; (4) to give students an opportunity to express their satisfaction with their academic experience. Academic institutions are becoming increasingly aware of the importance of students' satisfaction given that it positively influences their students' decision to continue their education at the institution in question, and on the positive word of mouth that will attract prospective students (Harrison Walker, 2014). Students' satisfaction also affects students' motivation, their attendance, and the increase in the income of educational institu- 
tions (Navarro Marzo et al., 2005, Schertzer, 2004). Many agree that quality leads to satisfaction, but some make distinction between the two terms, considering quality a general perception, and satisfaction a series of specific aspects (Bitner, 1990). Athiyaman (1997) believes that students' perception of quality has a strong impact on their post-role as a communication "means". From the students' perspective, high quality education creates better opportunities in terms of learning and knowledge, and they believe that the satisfaction or dissatisfaction strongly influences students' success or failure in learning (Aldridge, Rowley, 1998, retrieved from Li Wei, 2005). Educational aspects and class delivery aspects become one of the most important determinants of the perception of teaching quality and students' satisfaction (Elliot, Shin, 2002, Brown, 1998, Fraser, 1994, retrieved from Li Wei, 2005). While until recently management used to be an important factor in the teaching sector, management today assumes a different role, which is the intention and the will to satisfy students, and thus affects their perception of the service quality. All the attention is focused on the negative aspects of the model which emphasizes that dealing with dissatisfaction, and the aspects that lead to the said, can increase satisfaction. Therefore, the importance of administrative staff gets an increasingly important role in the process of meeting students' demands (Nyer, 2000). Badri et al. (2010) research is specific because of the measurement of parents' satisfaction at measuring satisfaction in schools/faculties, because they enable schooling to their children. In fact, parents' satisfaction is considered similar to users' satisfaction and their satisfaction influences the parents' loyalty to the school their child is attending (Bhote, 1996; Salisbury et al, 1997; Scheuing, 1995, cited from: Badri et al. 2010).

The complexity of meeting the criteria of the above mentioned factors has led many authors to closely examine students' satisfaction with the quality of student life. In their study, Sevda and Ozlem (2014) tried to determine the satisfaction with student life by including the variables of student life quality (social, scientific and service factors), life satisfaction, and identification. The study also attempted to evaluate the impact of the academic program of the chosen study, social life, and facilities and services provided at the faculty on the quality of student life as compared to other similar faculties in Turkey and other countries. Life satisfaction is the top priority of man in relation to the satisfaction with his society, family, friends, school, faculty, and health. According to the "bottom-up spillover" theory (Sirgy, 2010), all the mentioned variables affect life satisfaction. Satisfaction with student life affects life satisfaction. Based on this information, a study was conducted on how student life satisfaction affects the satisfaction with life in general (Sevda, Ozlem, 2014). A similar research was carried out in Croatia by Brkljačić and Kaliterna Lipovčan (2010), examining life satisfaction among students. Life satisfaction is a report on how one assesses and evaluates one's entire life.

Clewes (2003) suggests three different approaches to measuring the quality of education from students' perspective. Model on which the research was conducted 
is based on the modification of the SERVQUAL (Service Quality) model developed in 1988 by Parasuraman, A., Berry, L.L., Zeithaml, V.A. (1988, 1990, 1991). The first approach is based on the SERVQUAL method. However, in the studies based on the SERVQUAL instrument there was no consensus on which of the dimensions of quality had the key importance in higher education (tangibility, reliability, identification, trust and empathy), so the HEdPERF instrument was created precisely for researching the quality of higher education. The second approach in assessing the quality of higher education institutions is analysing students' satisfaction with only the quality of teaching and learning at a particular higher education institution. There is also the third approach, which uses the methods for assessing students' satisfaction with the overall student experience as an indicator of quality. Such researches cover various elements that contribute to students' satisfaction with the overall service of a higher education institution: the quality of teaching, course program and class organization, library services, registry services, IT support, work of the student union, accompanying services such as canteen services, accommodation, sports facilities, social life, entertainment and the like.

Some authors claim that students are customers and need to be treated as the customers of manufacturing companies. They are considered customers since they buy knowledge in order to satisfy their own needs for knowledge. Students' satisfaction with the overall faculty environment is essential for keeping them at the relevant faculty, as well as for their recommendations of the faculty to prospective students (Danjuma, Rasli, 2012). Many teachers are reluctant to accept the student-customer model, and are suspicious of every attempt at adapting student environment to the business concept (Mark, 2013). Machado, Brites, Magalhaes and Sa (2011) investigated the satisfaction with higher education as the key point in students' development. Numerous institutions recognize higher education as a "service sector", which is why they should put emphasis on meeting the expectations and needs of their customers, in the this case, their students. In order to better compete with other educational institutions, many faculties adopt a marketing oriented strategy to differentiate themselves from their competitors (Kotler and Fox 1995; Mihanović 2007, 2009; Pavičić, J.; Alfirević, N.; Mihanović, Z. 2007). It is important to have a good understanding of the target market (students), evaluate their needs, adapt the offer to meet the demand, and thus increase the satisfaction of the "customers" - students (Keegan, Davidson, 2004).

Researches have also been carried out with respect to the attitude of students towards their educational institution. This relationship is defined by two factors. One is persistence, with the aim of graduating from college and earning a diploma, and the other is the possibility of using the diploma in other institutions (Tinto, 1982, retrieved from Machado, Brites, Magalhaes, Sa, 2011). A faculty institution must constantly work on improving the services provided to their students. That way, the students will be satisfied with the service and therefore with the faculty (Elliot, Healy, 
2001). Certain authors have presented the dimensions of students' satisfaction with their faculty services, based on numerous researches. They proposed grouping these services into the following categories: facilities near the faculty, teaching staff, teaching methods, environment, enrolment, and services by other faculty bodies. All these services, which are under the direct control of the faculty, can be considered the determinants of students' satisfaction (Navarro Marzo et al., 2005). There are four groups of factors that influence students' satisfaction: institutional factors, extracurricular factors, students' expectations, and student demographics. Institutional factors therefore consist of academic (the quality of education, communication with the teachers in and outside the classes, textbooks and other teaching materials) and administrative (faculty practice and philosophy in administration) factors. Extra-curricular factors include social, health, cultural and sport activities, as well as transportation. Students' expectations represent the choice of faculty and employment opportunities after graduation. Demographic factors include age, gender, attendance, etc. (Aldemir, Gulcan, 2004). Rode et al. (2005) base their model (Figure 2.) on the perspective that they call "integrated life". This perspective illustrates how individual performances of a man influence his satisfaction in all life domains. They agree that the overall life satisfaction of students, and not just their satisfaction with their faculty as an institution, affects the performance of students, the ease of mastering the assigned tasks, and their involvement in the teaching process. The "Bottom-up" theory of life satisfaction suggests that life satisfaction represents the overall attitude which consists of the components of satisfaction with various life areas, but the impact of any specific variable of life on overall happiness varies depending on the population.

On the other hand, Gibson (2010) examined students' satisfaction and included some non-academic aspects therein, e.g. university reputation, contact personnel quality in administrative departments, acknowledgements and services, quality of teaching and IT facilities and student body diversity. Simomu and Dahl (2012) are based more on teaching quality analysis and the effect of that variable on students' satisfaction. They have examined the quality of teachers' performance, workload, social life, religious life, sports activities, family influence, employment opportunities, future expectations, difference between part-time and full-time students. Sergy et al. (2010) also examined the issue of students' satisfaction and its influences (Figure 3.). In their paper, these authors have based their research on the examination of satisfaction with the academic aspects of student life, e.g.: satisfaction with the faculty, satisfaction with the teaching methods, satisfaction with the class environment, satisfaction with the workload, satisfaction with the academic reputation and academic differences. Furthermore, the research included the social aspects of student life, such as: satisfaction with campus accommodation, satisfaction with international programmes and services, satisfaction with spiritual programmes and services, satisfaction with clubs and student social organisations and satisfaction 
with recreational activities. The authors have conducted this research by using two models. The first model included investigating how leisure, services, and academic and social aspects of life affect students' satisfaction with student life. The second, "extended" model included investigating how the satisfaction with student life affects the overall life satisfaction.

Figure 2.: Predicted Path Analytic Mode

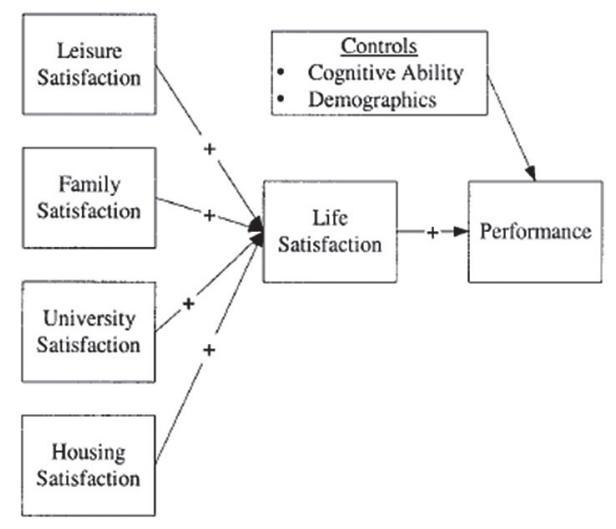

Source: Rode,C.,J.,et al., Life satisfaction and student performance, Academy of Management Learning \& Education,Vol. 4, No. 4, 4,21-4,33,2005

Figure 3.: The extended model

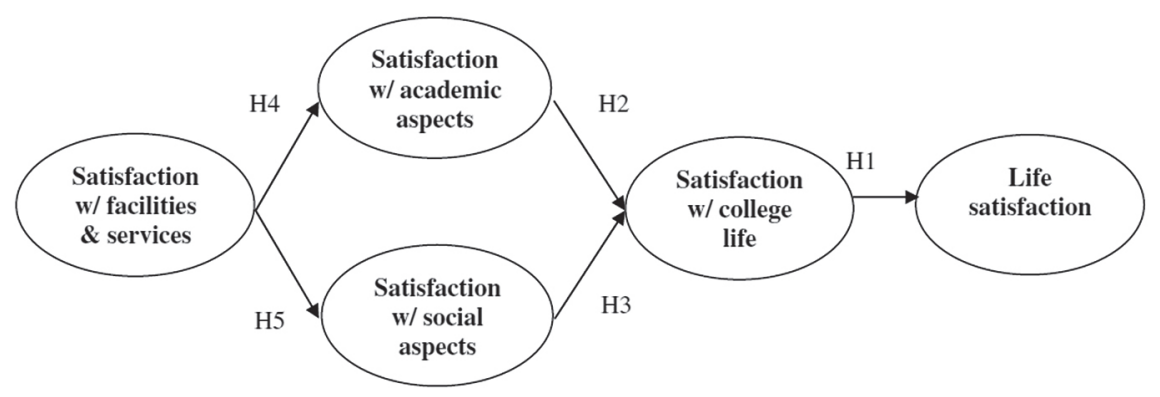

Source: Sirgy,M.,J.,et al., Quality of College Life (QCL) of Students: Further Validation of a Measure of Well-Being, Social Indicators Research, 12; 99(3). 2010. pp.384 


\section{MEASURING PERFORMANCE IN EDUCATIONAL SECTOR}

Measuring performance is still a major issue for businesses and other organizations (Meyer, 2002). In theory, but also in practice, measuring student performance is quite complex. There is no generally accepted procedure of measuring student performance, and individual researchers tend to conduct and explain it in their own way. Educational sector is a part of the public sector whose basic purpose is to satisfy the public needs. With the aim of monitoring the extent to which those needs have been met, many countries use different success indicators. Rowe (2004) describes them as indices by which data on functionality and quality of service providers and public sector are measured and assessed. In their paper Schochet and Chiang (2010) schematically divided performance measurement into two parts. In the first part the authors deal with the internal school issue: "Which teacher performs their job in a certain educational institution exceptionally well or exceptionally poorly with respect to all other teachers in that institution?", while in the second part they examine the inter-school issue: "Which teachers perform their job exceptionally well or exceptionally poorly with respect to all other teachers in the entire school district?". Furthermore, Rittschof and Chambers (2011), with the help of modern information graphs, tend to better understand the differences in the students' performances. Also, E. Umble and M. Umble (2012) conducted the performance measurements in a very interesting way. In fact, they illustrated the effect of the performance measurement system on the organisational performances among the students through the game "The Blue-Green Game"'. This game illustrated the significance of performance measurement, student encouragement system and their strength to reconsider their decisions on such an important subject. Hanushek (1996) studied in his paper the difference between performances of seventeen-year old students based on race and ethnical affiliation.

Rode et al. (2005) researched not only the effect of satisfaction with the faculty on students' performances, but the influence of the overall life satisfaction on them. Research has shown that the students who are more satisfied with their overall life have better results and cope more easily with studying challenges and vice versa. In both cases, the research has demonstrated that life satisfaction is important, not only from the aspect of influencing the social environment or keeping students, but academic performance as well. Numerous studies have shown that the satisfaction with particular life areas is in strong correlation with the overall life satisfaction (e.g., Andrews \& Withey, 1976; Campbell, Converse, \& Rodgers, 1976; Near, Smith, Rice, \& Hunt, 1983; Near, Smith, Rice, \& Hunt, 1984; Rice, Near, \& Hunt, 1979, cited from Rode et al., 2005). From all of the aforementioned, we can deduce that there are numerous possibilities for conducting performance measurements. Measuring student success is important for every higher education institution. Reliable measures of student success are necessary in order to assess the quality and effectiveness of the 
programs carried out at faculties, and to identify risk factors and factors of success. The researchers mainly focus their studies on students" "career", that is, on their success at the relevant faculty as measured by the grades which they earn in different courses at the faculty (Mossi, Venuleo, Tondo, Salvatore, 2012). The education sector is a part of the public sector which, as opposed to the profit sector, has the mission to meet public needs. In most countries, the public sector evaluation is done by using certain performance indicators. Rowe (2004) describes them as the indexes that measure and evaluate information on the functionality and quality of service providers and the public sector itself.

\section{EMPIRICAL RESEARCH}

\subsection{Research Model}

For the purposes of this study, a model was created that actually represents a combination of the models used by Rode et al. (2005) and Sirgy et al. (2010) in their research of students' satisfaction and performance. Performance was measured through students' grade point average, modelled after Rode's model. By combining these two models, the model shown in Figure 4. was created.

Figure 4.: Research mode

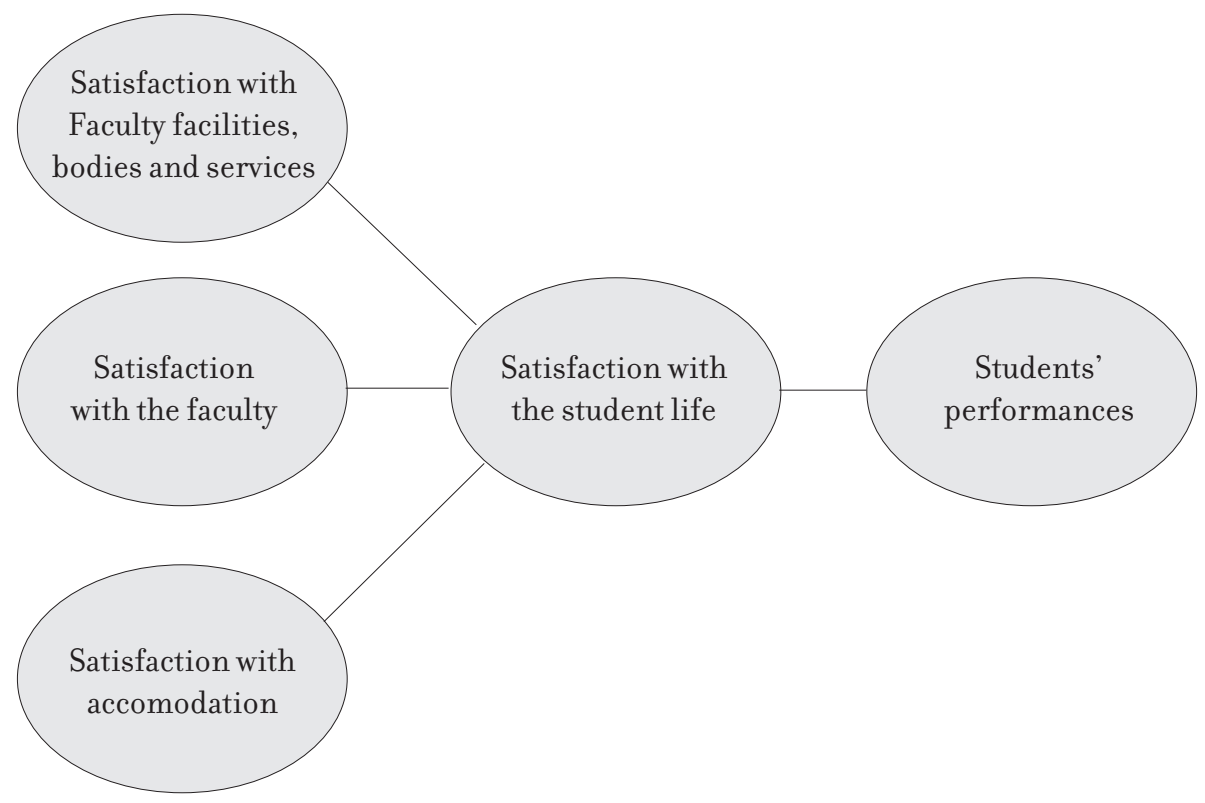

Source: authors' systematization 
Satisfaction with the student life encompasses the following aspects: (1) satisfaction with the faculty (teachers, teaching methods, academic reputation) - cited from Rode et al. (2005), in the original model, the influence of this item on the overall life satisfaction and performances was analysed; (2) faculty facilities, bodies and services (student registration office, library, infolab, parking) - cited from Sergy et al. (2010), in the original model, the influence of this variable on the satisfaction with academic and social aspects was analysed; (3) accommodation (whether the students live in dorms, private accommodation or with parents) - cited from Rode et al. (2005), the influence of this factor on the overall life satisfaction and students' performances was analysed.

By setting goals, modelled after the established model, we will attempt to determine the extent to which certain factors of life, both general and student life, affect the overall satisfaction with the studying experience, namely: what is the relationship between: (1) students' satisfaction with their faculty and students' satisfaction with student life; (2) students' satisfaction with the teaching methods and academic reputation and students' satisfaction with student life; (3) students' satisfaction with the faculty facilities, faculty bodies, and faculty services and the overall satisfaction with student life; (4) students' satisfaction with their housing and the overall satisfaction with student life; (5) students' satisfaction with student life and student performance.

The research was carried out by means of a questionnaire that contained 28 questions. The survey was conducted among the students of the University of Split, a total of 191. The survey was conducted at ten faculties in Split, namely: Faculty of Economics, Faculty of Electrical Engineering, Mechanical Engineering and Naval Architecture, Faculty of Civil Engineering, Faculty of Philosophy, Faculty of Maritime Studies, Faculty of Chemical Engineering and Technology, Faculty of Law, Faculty of Kinesiology, Faculty of Medicine, and Faculty of Natural Sciences.

\subsection{Research Results}

The study included $77 \%$ of women and $23 \%$ of men respondent. The largest number of respondents, $45 \%$ has between 21 and 23 years. From 24, to 26 years has $27.2 \%$ of respondents, from 18 to 20 years of age have $24.6 \%$ of respondents, while the smallest number of respondents, $3.2 \%$, is 27 years old and more. The largest number of respondents, $34 \%$ of them is on second year of graduate studies, $22.5 \%$ of them is on third year of undergraduate study, and $21 \%$ of them is on second year of undergraduate study. On the first year of graduate studies is $13.6 \%$ of respondents, while the smallest number of respondents are on the first year of undergraduate study, $8.9 \%$ of them. Most respondents have full-time status, $94.8 \%$ of them, while only $5.2 \%$ are part-time students. The largest number of participants is attending the Faculty of Humanities and Social Sciences, 24.6\% of them. This is followed by $16.2 \%$ of respondents who attend the School of Medi- 
cine, $13.6 \%$ of respondents who attend the Faculty of Economics. Faculty of Kinesiology attended $10.5 \%$ of respondents; Faculty of Law attended $8.4 \%$ of respondents, and the Faculty of Science attended $7.3 \%$ of respondents. Faculty of Civil engineering, Architecture and Geodesy attended 5.3\% of the respondents, $5.2 \%$ of respondents attended Faculty of Chemistry and Technology and the Faculty of Faculty of Electrical Engineering, Mechanical engineering and Naval Architecture. The minimum number of participants in this study attending the Faculty of Maritime Studies, $3.7 \%$ of them.

The first objective to examine is the impact of teaching methods and academic reputation on the total students' satisfaction with student life. The impact of teaching methods was observed through two variables: (1) adequate equipment of the faculty with technology for teaching and (2) interaction between teachers and students in class. The impact of the academic reputation was also observed by two variables: (1) reputation of the Faculty and (2) reputation of teachers. For the purpose of determining the connectedness of the observed variables, we will use the Pearson's linear correlation coefficient, which is also the most well-known measure of linear correlation and it will be conducted four tests to determine the impact of four claims to the total satisfaction of students with quality of student life.

Table 1. illustrates that Pearson's correlation coefficient amounts to $\mathrm{r}=0.385$, which means that there is a weak positive correlation between the satisfaction with well-equipped faculty with adequate technology and overall student satisfaction with the quality of student life.

Table 1.: The impact of Faculty equipment with adequate technology on Satisfaction with the quality of student life

\begin{tabular}{|l|r|r|r|}
\hline & & $\begin{array}{c}\text { Faculty equipment } \\
\text { with adequate } \\
\text { technology }\end{array}$ & $\begin{array}{c}\text { Satisfaction with the } \\
\text { quality of student } \\
\text { life }\end{array}$ \\
\hline $\begin{array}{l}\text { Faculty equipment } \\
\text { with adequate } \\
\text { technology }\end{array}$ & Pearson Correlation & 1 & 0,385 \\
Sig. (2-tailed) & $\mathrm{N}$ & 191 & 0,000 \\
Satisfaction with the & Pearson Correlation & 0,385 & 191 \\
quality of student life & Sig. (2-tailed) & 0,000 & 1 \\
& $\mathrm{~N}$ & 191 & 191 \\
\hline
\end{tabular}

Source: Author's.

Table 2. shows that methods of teaching and academic reputation in all cases have a positive impact on students' satisfaction with student life, and the growth of one variable will follow the growth of other variables. In three cases, it is a weak positive correlation (0.385; 0.395; 0.399), and in one case it is a medium-high positive correlation $(0.5 \circ 5)$. Based on the performed analysis it can be concluded that 
the grater the student's satisfaction with the methods of teaching and academic reputation the greater the satisfaction with the overall student life.

Table 2.: Value, the direction and intensity of Pearson linear correlation coefficient

\begin{tabular}{|l|r|r|}
\hline \multicolumn{1}{|c|}{ VARIABLES } & \multicolumn{1}{|c|}{$\begin{array}{c}\text { VAULE OFTHE } \\
\text { COEFFICIENT }\end{array}$} & \multicolumn{1}{c|}{$\begin{array}{c}\text { DIRECTIONAND THE } \\
\text { INTENSITY }\end{array}$} \\
\hline $\begin{array}{l}\text { adequate equipment of the } \\
\text { faculty with technology for } \\
\text { teaching }\end{array}$ & 0,385 & weak positive correlation \\
$\begin{array}{l}\text { interaction between teachers } \\
\text { and students in class }\end{array}$ & 0,395 & weak positive correlation \\
reputation of the Faculty & 0,399 & $\begin{array}{r}\text { weak positive correlation } \\
\text { medium strong } \\
\text { reputation of teachers }\end{array}$ \\
\hline
\end{tabular}

Source: Author's.

The second objective to examine is the impact of the university facilities, university authorities and services to the total satisfaction of students with student life. The impact is seen through the 12 claims. For the purpose of determining the connectedness of the observed variables, we will use the Pearson's linear correlation coefficient.

Table 3. shows that the content of university, university authorities and services has in all cases a positive impact on students' satisfaction with student life, and the growth of one variable will follow the growth of other variables. In eleven cases except speed of internet conection, it is a weak positive correlation. Based on the analysis it can be concluded that the grater the students satisfaction with the content of university, university authorities and services the greater the satisfaction with the overall student life.

Table 3.: Value, the direction and intensity of Pearson linear correlation coefficient

\begin{tabular}{|l|r|r|}
\hline \multicolumn{1}{|c|}{ VARIABLES } & $\begin{array}{c}\text { VAULE OF THE } \\
\text { COEFFICIENT }\end{array}$ & $\begin{array}{c}\text { DIRECTION AND THE } \\
\text { INTENSITY }\end{array}$ \\
\hline $\begin{array}{l}\text { Library staff } \\
\text { Reservations of place for } \\
\text { learning }\end{array}$ & 0,264 & weak positive correlation \\
$\begin{array}{l}\text { Organization of library } \\
\text { materials }\end{array}$ & 0,262 & weak positive correlation \\
Availability of materials for & 0,287 & weak positive correlation \\
teaching & 0,269 & weak positive correlation \\
Availability of computers & 0,334 & weak positive correlation \\
Info lab staff & 0,305 & weak positive correlation \\
Speed of Internet connection & 0,192 & no correlation \\
Equipment quality & 0,265 & weak positive correlation \\
Age of computers & 0,206 & weak positive correlation \\
\hline
\end{tabular}




\begin{tabular}{|l|c|c|}
\hline \multicolumn{1}{|c|}{ VARIABLES } & $\begin{array}{l}\text { VAULE OFTHE } \\
\text { COEFFICIENT }\end{array}$ & $\begin{array}{c}\text { DIRECTIONAND THE } \\
\text { INTENSITY }\end{array}$ \\
\hline $\begin{array}{l}\text { Availability of parking } \\
\begin{array}{l}\text { Sports and recreational } \\
\text { facilities }\end{array}\end{array}$ & 0,259 & weak positive correlation \\
$\begin{array}{l}\text { Kupovina knjiga i ostalog } \\
\text { materijala }\end{array}$ & 0,349 & weak positive correlation \\
\hline
\end{tabular}

Source: Author's.

The third objective to examine is the impact of satisfaction with accommodation on the overall satisfaction with the student life. Table 4 illustrates the structure of the respondents according to different forms of accommodation: dormitory accommodation, private renting accommodation, living with parents and their satisfaction with accommodation. For the purpose of establishing the connectedness of other observed variables, Pearson's linear correlation coefficient will be applied. Table 4. illustrates that the largest number of respondents live with their parents, and the smallest number of respondents is located in the dorms. We can also see that the majority of respondents, regardless of the type of housing, fully satisfied with accommodation.

Table 4.: Different forms of accommodation and students satisfaction with them

\begin{tabular}{|lr|r|r|r|r|r|r|}
\hline \multicolumn{7}{|c|}{ Satisfaction with accommodation } \\
\hline & & $\begin{array}{r}\text { completely } \\
\text { dissatisfied }\end{array}$ & $\begin{array}{r}\text { somewhat } \\
\text { satisfied }\end{array}$ & $\begin{array}{r}\text { nor } \\
\text { dissatisfied } \\
\text { neither } \\
\text { satisfied }\end{array}$ & $\begin{array}{r}\text { somewhat } \\
\text { satisfied }\end{array}$ & $\begin{array}{r}\text { fully } \\
\text { satisfied }\end{array}$ & Total \\
& & & & & & \\
accom- & no answer & 0 & 1 & 0 & 0 & 0 & 1 \\
modation & dormitory & 0 & 1 & 2 & 2 & 8 & 13 \\
& private & 2 & 8 & 13 & 13 & 9 & 45 \\
& With family & 1 & 1 & 20 & 29 & 81 & 132 \\
Total & & 3 & 11 & 35 & 44 & 98 & 191 \\
\hline
\end{tabular}

Table 5. shows that Pearson's correlation coefficient amounts to $\mathrm{r}=0.092$, which means that there is no correlation between the satisfaction with accommodation and the overall satisfaction with the student life and students' satisfaction with accommodation does not impact overall satisfaction with the student life.

Source: Author's. 
Table 5.: The impact of satisfaction with accommodation on the overall satisfaction with the student life

\begin{tabular}{|l|r|r|r|}
\hline & & $\begin{array}{c}\text { Satisfaction with } \\
\text { accommodation }\end{array}$ & $\begin{array}{c}\text { Satisfaction with the } \\
\text { student life }\end{array}$ \\
\hline Satisfaction with & Pearson Correlation & 1 & $-0,092$ \\
accommodation & Sig. (2-tailed) & & 0,207 \\
N & Nearson Correlation & 191 & 191 \\
Satisfaction with the & Sig. (2-tailed) & $-0,092$ & 1 \\
studentlife & N & 0,207 & 191 \\
\hline
\end{tabular}

Source: Author's.

The final goal of this paper is to examine the impact of student satisfaction with student life on student performance on University of Split. The performances of students are observed through three variables: regularity of completing the years of study, mastering the knowledge, acquiring the faculty curriculum, and the general success at the faculty. At the beginning it will be examine the relationship between student satisfactions with student life due to the regularity of completing the years of study, Table 6. For the purpose of establishing the connectedness of other observed variables, Pearson's linear correlation coefficient will be applied in two tests.

In Table 6., it can be seen that the greatest number of respondents regularly completed the years of study, and the smallest number of respondents is repeated more than one year. We can also see that the majority of respondents, regardless of the regularity of completing the study, satisfaction with the quality of student life rated as very good, while the smallest number of respondent's satisfaction with the quality of student life rated as insufficient.

Table 6.: The respondents' satisfaction and regularity of completing the years of study

\begin{tabular}{|c|c|c|c|c|c|}
\hline \multicolumn{6}{|c|}{ Regularity of completing the years of study } \\
\hline & & $\begin{array}{l}\text { I repeated } \\
\text { more years }\end{array}$ & $\begin{array}{r}\text { I repeat only } \\
\text { one year }\end{array}$ & $\begin{array}{l}\text { I regularly } \\
\text { passed all }\end{array}$ & Total \\
\hline \multirow{5}{*}{$\begin{array}{l}\text { student } \\
\text { satisfactions } \\
\text { with student } \\
\text { life }\end{array}$} & insufficient & 1 & 4 & 5 & 10 \\
\hline & sufficient & 1 & 9 & 10 & 20 \\
\hline & good & 4 & 14 & 43 & 61 \\
\hline & very good & 5 & 12 & 63 & $8 \circ$ \\
\hline & excellent & ० & 6 & 14 & 20 \\
\hline Total & & 11 & 45 & 135 & 191 \\
\hline
\end{tabular}

Source: Author's.

From Table 7 . it can be concluded that student satisfaction with student life has weak positive impact on mastering the knowledge, acquiring the faculty curriculum 
and general success at the faculty. In both cases it is a weak positive correlation ( 0.261 ; 0.258 ). Based on the analysis it can be concluded that students who are more satisfied with the overall student life have better student performance.

Table 7.: Value, the direction and intensity of Pearson linear correlation coefficient

\begin{tabular}{|l|r|r|}
\hline \multicolumn{1}{|c|}{ VARIABLES } & $\begin{array}{l}\text { VAULE OF THE } \\
\text { COEFFICIENT }\end{array}$ & $\begin{array}{c}\text { DIRECTION AND THE } \\
\text { INTENSITY }\end{array}$ \\
\hline $\begin{array}{l}\text { mastering the knowledge, } \\
\text { acquiring the faculty curriculum } \\
\text { general success at the faculty }\end{array}$ & 0,261 & weak positive correlation \\
weak positive correlation \\
\hline
\end{tabular}

Source: Author's.

In addition, it was also tested satisfaction with the quality of student life in relation to the faculty that respondents attending, Table 8.

Table 8.: Satisfaction with the quality of student life in relation to the faculty that respondents attending

\begin{tabular}{|c|c|c|c|c|c|c|c|}
\hline & & \multicolumn{6}{|c|}{ Satisfaction with the quality of student life } \\
\hline & & $\begin{array}{l}\text { insuf- } \\
\text { ficient }\end{array}$ & $\begin{array}{l}\text { suffi- } \\
\text { cient }\end{array}$ & good & $\begin{array}{l}\text { very } \\
\text { good }\end{array}$ & $\begin{array}{l}\text { excel- } \\
\text { lent }\end{array}$ & Total \\
\hline & $\begin{array}{r}\text { Faculty of } \\
\text { Economics }\end{array}$ & ० & o & 8 & 14 & 4 & 26 \\
\hline & $\begin{array}{r}\text { Faculty of } \\
\text { Electrical } \\
\text { Engineering, } \\
\text { Mechanical } \\
\text { engineering } \\
\text { and Naval } \\
\text { Architecture }\end{array}$ & 0 & ० & 2 & 5 & 3 & 10 \\
\hline & $\begin{array}{r}\text { Faculty of } \\
\text { Humanities } \\
\text { and Social } \\
\text { Sciences }\end{array}$ & 5 & 3 & 17 & 19 & 3 & 47 \\
\hline Faculty & $\begin{array}{r}\text { Faculty of Civil } \\
\text { engineering, } \\
\text { architecture } \\
\text { and Geodesy }\end{array}$ & ० & 1 & 1 & 5 & 3 & 10 \\
\hline & $\begin{array}{l}\text { School of } \\
\text { Medicine }\end{array}$ & ० & 3 & 11 & 13 & 4 & 31 \\
\hline & $\begin{array}{r}\text { Faculty of } \\
\text { Kinesiology }\end{array}$ & ० & 1 & 6 & 11 & 2 & 20 \\
\hline & $\begin{array}{r}\text { Faculty of } \\
\text { Chemistry and } \\
\text { Technology }\end{array}$ & 2 & 3 & 3 & 2 & $\circ$ & 10 \\
\hline & $\begin{array}{r}\text { Faculty of } \\
\text { Maritime } \\
\text { studies }\end{array}$ & 0 & 2 & 3 & 1 & 1 & 7 \\
\hline
\end{tabular}




\begin{tabular}{|r|r|r|r|r|r|r|r|}
\hline & \multicolumn{6}{|c|}{ Satisfaction with the quality of student life } \\
\hline & Faculty of Law & 3 & 3 & 4 & 6 & 0 & 16 \\
Faculty of & 0 & 4 & 6 & 4 & 0 & 14 \\
Science & 10 & 20 & 61 & 80 & 20 & 191 \\
\hline
\end{tabular}

Source: Author's.

\section{CONCLUSION}

The main goal of this study was to determination the extent to which certain factors of life, both general and student life, affect the overall satisfaction with the studying experience and how this is connected with students performances. The survey was conducted among the students of the University of Split, a total of 191. Students' satisfaction is becoming an increasingly important variable in the success of an educational institution because the reputation of the institution and the number of prospective students enrolled depends on it. Faculties must be willing to introduce changes in order to become more competitive. It is crucial that faculties invest in knowledge, i.e. in teacher training, teaching methods, faculty facilities, and so on. In this research it has been found that the greater the students' satisfaction with their faculty facilities, faculty bodies, and faculty services, the greater the overall satisfaction with student life is. We observed the effects of the following factors on the satisfaction with student life: library staff, reserving a place for studying, organization of library materials on the shelves, availability of learning materials, availability of computers, infolab staff, the Internet speed, equipment quality, age of computers, availability of parking, sports and recreational facilities, and purchase of books and other materials. The variable that influences the satisfaction with student life most is the purchase of books and other materials. The variable that has no influences on satisfaction with student life is the Internet speed. The said points to the fact that additional facilities at the faculties represent an important item of impact on students' satisfaction. Students spend more time in libraries and infolabs and widely use the stores where they can get the necessary books and teaching materials. Timely investment in these segments will ensure a positive image of the faculty, and the students will be more willing to replace their homes with the very faculty as a place for learning, and preparing seminar and other papers. Likewise, we have rejected the claim that the greater students' satisfaction with housing, the greater their overall satisfaction with student life is. Although it was expected that the satisfaction with accommodation affects the satisfaction with the quality of student life, the analysis did not show this, perhaps mostly because the majority of the respondents lived with their parents. Students are satisfied with student life when their faculty is adequately equipped with the technology necessary for teaching, and when there is a good interaction between the teachers and students in class. Students are also satisfied 
with the quality of student life when they trust that the reputation of their faculty is positive and that the reputation of their teachers is also positive. The said points to the fact that faculties must systematically invest in the technology needed to carry out high quality teaching, as well as in their own staff through the opportunities of teacher training and familiarizing the teachers with the new opportunities of working and communicating with students. It is certain that more changes will be introduced in the forthcoming years, and that teachers and faculties will have to be ready to adapt to the changes in the education system in order to make their students more satisfied.

Ultimately, it has been found that higher students' satisfaction with student life has an impact on students' better performance. When analysing the impact of students' satisfaction with the quality of student life on their performance, we observed the variables of the regularity of completing the years of study, mastering the knowledge, acquiring the faculty curriculum, and the general success at the faculty. The acquisition of the faculty curriculum had a slightly greater impact than the general success at the faculty. Looking at the analysis of the satisfaction with the quality of student life in relation to the faculties, there were several conclusions. Certain students from the Faculty of Humanities and Social Sciences, Faculty of Law, and Faculty of Chemistry and Technology were the only ones who assessed their satisfaction with the quality of student life with the grade insufficient, so it can be said that these faculties have to work mostly on their reputation and quality in order to achieve a greater satisfaction of their students. The faculties that demonstrated a kind of "golden mean", the majority of whose students assessed their satisfaction with the quality of student life with the grade good, are the Faculty of Maritime Studies, School of Medicine, and Faculty of Science. These faculties must surely also work on improving their quality and reputation in order to ensure a greater satisfaction of their students. The faculties awarded the highest grades (very good and excellent) by the students were the Faculty of Kinesiology, Faculty of Economics, Faculty of Civil engineering, Architecture and Geodesy, and Faculty of Electrical Engineering, Mechanical engineering and Naval Architecture as 50\% or more of their students assessed their faculties with the grade very good and excellent. These results confirm the assumption that all faculties must work to keep pace with new technologies, and invest in their teachers and other staff, and then in the faculty facilities that include libraries, IT labs, and sports and recreational facilities. Regardless of the fact that the hypothesis on the satisfaction with housing was rejected, it is still necessary to invest in the quality of student dormitories. All the mentioned variables will have an impact on the further student performance at the faculties. The future also provides an opportunity to conduct a similar research at all the universities in Croatia, as well as to observe other relevant factors of satisfaction, particularly those of more personal nature (religion, extracurricular activities, relationship with other students, health, etc.). 


\section{REFERENCES:}

Aldemir, G., Gülcan, Y., "Student Satisfaction in Higher Education", Higher Education Management and Policy, No.: 19, Volume: 16, Issue: 2, (2004): 109-122

Anderson, E. W., \& Sullivan, M. W., "The antecedents and consequences of customer satisfaction for firms", Marketing Science, 12, (1993): 125-143

Athiyaman, A., "Linking Student Satisfaction and Service Quality Perception: The case of university education", European Joumal of Marketing, Vol. 31, (7), (1997): 528-54.

Badri, M., et al., "A modified customer-satisfaction index model for the education sector in Abu Dhabi", International Journal of Business and Public Administration, Volume 7, Numberı, (2010): 148-159

Batinić, A. B. "Utjecaj zadovoljstva studenata fakultetom i studentskim životom na studentske performance - primjer Sveučilišta u Splitu”, Diplomski rad, Ekonomski fakultet Split, (2015)

Bitner, M.J., "Evaluating Service Encounters: The effect of physical surrounding and employee responses", Journal of Marketing, Vol. 54, (1), (1990): 69-82

Budak, J., Slijepčević, S., Švaljek, S. "Financijske potpore studentima u sustavu visokog obrazovanja u Republici Hrvatskoj", Ekonomski institut, Zagreb, (2009)

Brkljačić, T., Kaliterna.,Lipovčan, Lj., "Zadovoljstvo životom i osjećaj sreće kod studenata", Suvremena psihologija 13, (2010)

Clewes, D., "A student-centred conceptual model of service quality in higher education", Quality in higher education, Vol.9, NO. 1, (2003)

Danjuma, I., Rasli, A., "Service quality, satisfaction and attachment in higher education institutions: A theory of planned behaviour perspective", International journal of academic research, Vol.4. No. 2., (2012): 96

Douglas, J., Douglas, A., Barnes, B., "Measuring student satisfaction at a UK university", Quality Assurance in Education, Vol. 14, Iss: 3, (2006): 251-267

Dubrovski, D., "The role of customer satisfaction in achieving business excellence", TQM, Vol. 12, NO. 7\&8, (2001): 920-925

Elliot, K. M., \& Healy M. A., "Keyfactors influencing student satisfaction related to recruitment and retention", Journal of Marketing for Higher Education, 10, (2001): 1-11

Eurostat, (2012) http://ec.europa.eu/eurostat/documents/3217494/5735241/EG-3o-12-534-EN.PDF/ ffbob7c9-bf5e-4696-984f-ao5bi35fe5a3

Gelade, G.A., Young, S., "Test of a service profit chain model in the retail banking sector", Journal of occupational and organizational psychology, $78,(2005): 1-22$

Gibson, A., "Measuring business student satisfaction: a review and summary of the major predictors", Journal of Higher Education Policy and Management Vol. 32, No. 3, (2010): 252-257

Glavočević, A., Radman-Peša, A., "Društveno odgovorno poslovanje i CRM kao način integriranja društvene odgovornosti u marketinške aktivnosti", Oeconomica Jadertina (2013)

Gupta S. i Pirsch J., "A Taxonomy of Cause-Related Marketing Research: Current Findings and Future Research Directions", Journal of Nonprofit \& Public Sector Marketing, Vol. 15Issue 1/2, (2006) 25-43, $19 \mathrm{p}$ 
Gupta S. i Pirsch J., "The company-cause-customer fit decision in cause-related marketing", Journal of Consumer Marketing, Vol. 23 Iss: 6, (2006): 314, - 326

Haralambos, M. i Holborn, M., Sociologija: Teme i perspektive. Zagreb, Golden Marketing, (2002)

Harrison Walker, L.J., "When opposites detract: Student (dis)satisfaction in higher education and the importance of compatibility management", Academy of Educational Leadership Journal, Volume 18, Numberı, (2014)

Harter, J. K., Schmidt, F. L., \& Hayes, T. L., "Business-unit-level relationship between employee satisfaction, employee engagement, and business outcomes: A meta-analysis", Journal of Applied Psychology, 87, (2002): 268-279

Heskett, J. L., Sasser, W. E., Jr, \& Schlesinger, L. A., The service profit chain. New York: Free Press., (1997)

Izmjene i dopune Zakona o visokim učilištima, Narodne novine 48/95, 14. srpnja 1995.

Izmjene i dopune Zakona o visokim učilištima, Narodne novine 29/96, 17. travnja 1996.

Keegan, W. \& Davidson, H., Offensive marketing: gaining competitive advantage, Elsevier Inc., Amsterdam, (2004)

Kesić, T.: Ponašanje potrošača, Opnio, Zagreb, (2006)

Kotler, P., Fox, K.F.A.: Strategic marketing for educational institutions. Prentice Hall, New Jersey, (1995)

Li-Wei, Mai., "A comparative study between UK and US: The student satisfaction in higher education and its influential factors", Journal of marketing management, 21, (2005): 859-878

Lučin, P., "Osiguranje kvalitete u Europskom visokoobrazovnom prostoru", Nakladna zaklada za znanost, visoko školstvo i tehnologijski razvoj Republike Hrvatske, Rijeka, (2007): 5, 8, 13, 17

Machado, M., L., Brites, R., Magalhaes, A., Sa, M.,.., "Satisfaction with Higher Education: critical data for student development", European Journal of Education, Vol. 46, No. 3, (2011)

Mark, E., "Student satisfaction and the customer focus in higher education", Journal of Higher Education Policy and Management, Vol. 35. No. 1 2-10, (2013)

Meyer, M.: Rethinking performance measurement, Beyond the balanced scorecard, The Wharton School, University of Pennsylvania, (2002)

Mihanović, Z.: „Uloga korisnika u visokom obrazovanju: jesu li studenti aktivni dionici?“" (The role of customers in higher education: are students active stakeholders?) Tržište, Vol. XIX, br. 1., (2007): 115-132

Mihanović, Z., Zekić, K., Influence of students' satisfaction with student life quality on their performance: The case of Higher education institutions in Portugal, ICQH, Proceedings Book, Sakarya / Turkey, (2015): $205^{-217}$

Mihanović, Z., Arnerić, J., Pepur, M.: „Differences Testing Between Clusters: Evidence From Market Orientation of Croatian Faculties", Proceedings of the 1oth International Symposium on OPERATIONAL RESEARCH, Nova Gorica, Slovenia, Slovenian Society Informatika (SDI), Section for Operational Research (SOR), (2009): 535-544

Mossi, P., Venuleo, G., Tondo, P., Salvatore, S., "The measurement of students performance. The use of an extended Rasch model for the analysis of predictors of high educational performance", Electronic Journal of Applied Statistical Analysis, Vol. 5, Issue 3, (2012): 393 - 399

Navarro Marzo, M., Pedraja Iglesias, M., Rivera Torres, P., "A new management element for universities: 
satisfaction with the offered courses", International Journal of Educational Management, Vol. 19 Iss: 6, $(2005): 5 \circ 5-526$

Nyer, P.U., "An Investigation into Whether Complaining Can Cause Increased Consumer Satisfaction", Journal of Consumer Marketing, Vol. 17, (1), (2000): 9-19

O'Neill, M.A.,Palmer, A., "Importance performance analysis: a useful tool for directing continuous quality improvement in higher education", Quality Assurance in Education, Vol. 12 Iss: 1, (2004): 39 - 52

Parasuraman, A., Berry, L.L., Zeithaml, V.A.: "SERVQUAL: A multiple-item scale for measuring consumer perceptions of service quality", Journal of Retailing, Vol. 64, No. 1, (1988): 12-4,

Parasuraman, A., Berry, L.L., Zeithaml, V.A.: "Refinement and Reassessment of the SERVQUAL Scale", Journal of Retailing, Vol. 67, No. 4, (1991): 420-450

Pavičić, J.: Strategija marketinga neprofitnih organizacija, Masmedia, Zagreb, (2003)

Pavičić, J.; Alfirević, N.; Mihanović,Z.: "Market orientation in managing relationships with multiple constituencies of Croatian higher education", Higher Education, Vol. 57, No. 2, (2007): 191-207

Polonsky M. i Speed R., Linking sponsorship and cause related marketing: Complementarities, and conflicts, European Journal of Marketing, Vol. 35 Iss: 11/12, (2001): 1361 - 1389

Rittschof,K.,Chambers,W., "Modern Measurement Information Graphics for Understanding Performance: The Blue-Green Game, Decision Sciences", Journal of Innovative Education, (2011): 462-4,66

Rode, C.,J., et al., "Life satisfaction and student performance", Academy of Management Learning \& Education, (2005): 421-4.25

Rogers, P., Saenz, H., "Make your back office an accelerator", Harvard Business Review, Vol. 85, No. 3, Australian Council for Educational Research, (2007)

Rowe, Ken J., "Analysing and Reporting Performance Indicator Data: „Caress" the data and user beware!”, (2004)

Sander, P., Stevenson, K., King, M. \& Coates, D., "University Students' Expectations of Teaching", Studies in Higher Education, Volume 25, Issue 3, (2000): 309-323

Sevda, A., Ozlem, A., A., "Quality of College Life (QCL) of Students in Turkey: Students' Life Satisfaction and Identification", Social Indicators Research, Volume 115, Issue 2, (2014): 869-884.

Schertzer Clinton, B. \& Schertzer Susan M. B., "Student Satisfaction and Retention: A Conceptual Model", Journal of Marketing for Higher Education, 14:1, (2004): 79-91

Sirgy, M.J.,et al., "Quality of College Life (QCL) of Students: Further Validation of a Measure of WellBeing", Social Indicators Research, 12; 99(3), (2010): $375^{-390}$

Siri, N. Espy, "Keep the customer satisfied", Non-profit world, Vol. 5, No. 4, (1987)

Schochet,P.,Z., Chiang,H.,S., "Error Rates in Measuring Teacher and School Performance Based on Student Test Score Gains", Mathematica Policy Research, (2010): 8-10

Smimou, K., Dalh, W.D., "On the Relationship Between Students' Perceptions of Teaching Quality, Methods of Assessment and Satisfaction", Journal of education for business, (2012)

Srbljinović M., "Utjecaj društvene odgovornosti poduzeća na ponašanje potrošača u Hrvatskoj", Zbornik Ekonomskog fakulteta u Zagrebu, Vol.10 No.2, (2012): 161 -180

Šćukanec, N.: Nastanak zajedničke visokoobrazovne politike na razini Europske unije, Institut za razvoj obrazovanja, Zagreb, (2010) 
Vranešević, T.: Upravljanje zadovoljstvom klijenata, Golden marketing, Zagreb, (2000)

Yeung, M.C.H., Ennew, C.T., "Measuring the impact of customer satisfaction on profitability: A sectoral analysis", Journal of targeting, measurement and analysis for marketing, Vol. 10, 2, (2001): 106-116

Zekić, K. Zadovoljstvo studenata kvalitetom studentskog života na primjeru Ekonomskog fakultea u Aveiru, Diplomski rad, Ekonomski fakultet Split, (2015)

Zeithaml, V.A., Parasuraman, A. and Berry, L.L., Delivering Service Quality, Free Press, New York, NY. (1990) 